\title{
Synthesis of Enaminones with Stationary Stereochemistry
}

\author{
Alberto Wisniewski Junior, Alfredo R.M. Oliveira, Carlos Jorge da Cunha, \\ Fabio Simonelli and Francisco A. Marques*
}

Departamento de Química, Universidade Federal do Paraná, C.P. 19081, 81531-990 Curitiba - PR, Brazil

\begin{abstract}
Cinco enaminonas 4a-e, derivadas da reação do ânion da 2,4,4-trimetil-2-oxazolina com acetato de etila, benzoato de etila, ciclohexanoato de etila, hexanoato de etila e $p$-metil benzoato de etila, respectivamente, foram preparadas e caracterizadas por $\mathrm{RMN}^{1} \mathrm{H}, \mathrm{RMN}{ }^{13} \mathrm{C}$, FTIR e EM. As enaminonas $\mathbf{4 a}$ e $\mathbf{4 b}$ também foram analisadas pela técnica de difração de raios-X. A enaminona $\mathbf{4 a}$ cristalizou-se no sistema monoclínico $\mathrm{P} 2(1) / \mathrm{n}$, grupo espacial com a $=9.1450(20) \AA, \mathrm{b}=$ $10.5150(20) \AA, c=9.5670(20) \AA, \beta=106.21(30)^{\circ}, Z=4$. A enaminona $4 \mathbf{b}$ cristalizou-se no sistema monoclínico $\mathrm{P} 2(1) / \mathrm{c}$, grupo espacial com a $=16.0520(30) \AA, \mathrm{b}=26.0460(50) \AA, \mathrm{c}=12.3520$ (20) $\AA$, $\beta=111.900(30)^{\circ}, Z=4$. Todas as cinco enaminonas possuem uma extensa delocalização de elétrons $\pi$ e a mesma configuração para a ligação dupla, a qual é fixada por ponte de hidrogênio intramolecular entre os grupamentos $\mathrm{NH}$ e $\mathrm{C}=\mathrm{O}$.
\end{abstract}

Five enaminones 4a-e derived from the reaction of 2,4,4-trimethyl-2-oxazoline anion with ethyl acetate, ethyl benzoate, ethyl cyclohexanoate, ethyl hexanoate and ethyl $p$-methyl benzoate, respectively, were obtained and characterized by ${ }^{13} \mathrm{C}-\mathrm{NMR},{ }^{1} \mathrm{H}-\mathrm{NMR}, \mathrm{FTIR}$, and mass spectral analysis. The enaminones $\mathbf{4 a}$ and $\mathbf{4 b}$ were also analysed by X-ray diffraction. Enaminone $\mathbf{4 a}$ crystallized in the monoclinic P2(1)/n space group with $\mathrm{a}=9.1450(20) \AA, \mathrm{b}=10.5150(20) \AA, \mathrm{c}=9.5670$ (20) $\AA$, $\beta=106.21(30)^{\circ}, Z=4$. Enaminone $4 \mathbf{b}$ crystallized in the monoclinic $P 2(1) / c$ space group with $\mathbf{a}=$ $16.0520(30) \AA, b=26.0460(50) \AA, c=12.3520$ (20) $\AA, \beta=111.900(30)^{\circ}, Z=4$. All five enaminones were found to have an extensive $\pi$ electron delocalization and to have the same configuration where the double bond is trapped by an internal hydrogen bond between the $\mathrm{NH}$ and the $\mathrm{C}=\mathrm{O}$.

Keywords: enaminones, 2-oxazolines, intramolecular hydrogen bonding

\section{Introduction}

As part of our ongoing work exploring the chemistry of 2-oxazolines ${ }^{1}$ we became interested in the preparation of chiral $\beta$-hydroxy-2-oxazolines 1 since enantiomerically pure secondary alcohols are useful chiral auxiliaries in organic chemistry both for analytical and synthetic applications $^{2}$. In particular the oxazoline moiety of these compounds could easily be converted into other functional groups such as carboxylic acids, alcohols, aldehydes,

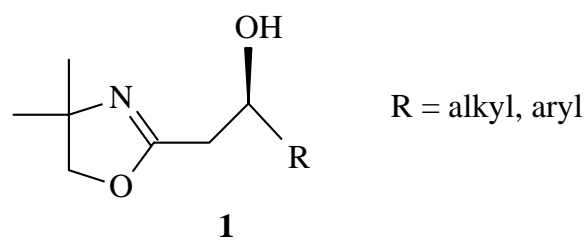

Figure 1. $\beta$-hydroxy-2-oxazoline. among others ${ }^{3}$, increasing its value as chiral synthons to be applied in organic synthesis.

Chiral secondary alcohols have been mainly obtained from the corresponding ketones by asymmetric hydrogenation $^{4}$, by treatment with a hydride reagent modified with a chiral auxiliary ${ }^{4}$, or by microbial reduction with baker's yeast ${ }^{5}$ or other microorganisms ${ }^{6,7}$. We have chosen to prepare the desired $\beta$-hydroxy-2-oxazolines by asymmetric reduction of $\beta$-keto-2-oxazolines with baker's yeast. In an attempt to prepare $\beta$-keto-2-oxazolines, we have obtained isomeric enaminones, instead. The present work describes the synthesis and characterization of five such enaminones.

\section{Experimental}

\section{General}

Nuclear magnetic resonance (NMR) spectra were recorded in $\mathrm{CDCl}_{3}$ with a Bruker AC-400 or with a Varian

*e-mail: tic@quimica.ufpr.br 
GEMINI-300BB instrument using tetramethylsilane as an internal standard. The infrared spectra were recorded on a Bomem MB-100 spectrophotometer. The mass spectra were obtained with a Shimadzu GC-MS-QP5000 instrument equipped with a DB-5 column (30 $\mathrm{m}$ x 0,25 mm) and the data are reported as $\mathrm{m} / \mathrm{z}$ (abundance). Capillary gas chromatography analyses were performed on a Shimadzu GC-14B chromatograph equipped with a DB-5 column (30 $\mathrm{m} \times 0,25 \mathrm{~mm})$. Flash chromatography was carried out on E. Merck silica gel 60 (230-400 mesh). All reactions were monitored by thin layer chromatography (TLC) or by capillary GC.

\section{Typical procedure for the preparation of enaminone $4 \mathrm{a}$ as representative}

n-Butyllithium in hexane $(13.6 \mathrm{~mL}, 22 \mathrm{mmol})$ was added dropwise at $-78{ }^{\circ} \mathrm{C}$ to a solution of 2,4,4-trimethyl2-oxazoline (2.486 g, $22 \mathrm{mmol})$ in dry THF (20 mL), under nitrogen. After stirring for 30 minutes, the resulting solution was added, at $-10^{\circ} \mathrm{C}$, to a round bottom flask containing ethyl acetate $(3.872 \mathrm{~g}, 44 \mathrm{mmol})$ in dry THF $(10 \mathrm{~mL})$. The chilling bath was removed and the reaction mixture was stirred for $30 \mathrm{~min}$ at room temperature. Water was added to the reaction flask up to the formation of an emulsion, which was dried over anhydrous $\mathrm{Na}_{2} \mathrm{SO}_{4}$. After filtration, the solvent was removed under reduced pressure and the product was purified by flash chromatography on silica gel using a mixture of hexane:ethyl acetate (1:1 ratio), yielding $2.25 \mathrm{~g}(66 \%)$ of enaminone $4 \mathbf{a} . \mathrm{mp} 126-128{ }^{\circ} \mathrm{C}$. ${ }^{1} \mathrm{H}-\mathrm{NMR}\left(\mathrm{CDCl}_{3}, 400 \mathrm{MHz}\right) \delta 4.88(\mathrm{~s}, 1 \mathrm{H}, \mathrm{C}=\mathrm{CH}-), 4.08$ (s, $\left.2 \mathrm{H},-\mathrm{CH}_{2}-\mathrm{O}-\right), 2.02$ (s, 3H, $\left.\mathrm{CH}_{3} \mathrm{CO}-\right), 1.39$ (s, $6 \mathrm{H},-\mathrm{CH}_{3}$ ); ${ }^{13} \mathrm{C}-\mathrm{NMR}\left(\mathrm{CDCl}_{3}, 100 \mathrm{MHz}\right) \delta 194.14,168.21,78.60$, 76.76, 58.23, 28.66, 26.93; MS (70 eV): m/z $(\%)=155$ $\left(\mathrm{M}^{+}\right), 140$ (100), 113, 98, 82, 70, 55; IR (KBr) 3257, 1627, $1552 \mathrm{~cm}^{-1}$; Anal. Calcd. for $\mathrm{C}_{8} \mathrm{H}_{13} \mathrm{NO}_{2}$ : C, 61.9; $\mathrm{H}, 8.4 ; \mathrm{N}$, 9.0. Found: C, 62.0; H, 8.4; N, 9.2.

Enaminones $4 \mathbf{b}$-e were prepared in a similar way by replacing ethyl acetate with ethyl benzoate, ethyl cyclohexanoate, ethyl hexanoate and ethyl $p$-methyl benzoate, respectively.

Physical and spectroscopic data for $4 \mathrm{~b}$ : $\mathrm{mp} 101-103{ }^{\circ} \mathrm{C}$. ${ }^{1} \mathrm{H}-\mathrm{NMR}\left(\mathrm{CDCl}_{3}, 400 \mathrm{MHz}\right) \delta 7.87-7.83\left(\mathrm{~m}, 2 \mathrm{H}, o^{-}\right.$ phenyl), 7.40-7.38 (m, 3H, m,p-phenyl), $5.58(\mathrm{~s}, 1 \mathrm{H}$, $\mathrm{C}=\mathrm{CH}-), 4.15$ (s, 2H, - $\left.\mathrm{CH}_{2}-\mathrm{O}-\right), 1.44$ (s, 6H, $\left.-\mathrm{CH}_{3}\right) ;{ }^{13} \mathrm{C}-$ $\mathrm{NMR}\left(\mathrm{CDCl}_{3}, 100 \mathrm{MHz}\right) \delta 187.53,169.63,140.02,130.56$, 128.15, 126.84, 78.98, 74.07, 58.58, 27.14; MS (70 eV): $\mathrm{m} / \mathrm{z}(\%)=217\left(\mathrm{M}^{+}\right), 202,140(14), 105$ (100), 77, 55, 41; IR (KBr) 3246, 1614, $1570 \mathrm{~cm}^{-1}$; Anal. Calcd. for $\mathrm{C}_{13} \mathrm{H}_{15} \mathrm{NO}_{2}$ : C, 71.9; H, 7.0; N, 6.4. Found: C, 69.7; H, 6.9; $\mathrm{N}, 6.7$.

Physical and spectroscopic data for $4 \mathbf{c}$ : $\mathrm{mp} 83-85^{\circ} \mathrm{C}$. ${ }^{1} \mathrm{H}-\mathrm{NMR}\left(\mathrm{CDCl}_{3}, 300 \mathrm{MHz}\right) \delta 4.86(\mathrm{~s}, 1 \mathrm{H},-\mathrm{C}=\mathrm{CH}-), 4.05$ (s, $2 \mathrm{H},-\mathrm{CH}_{2} \mathrm{O}-$ ), 2.13 (tt, $\mathrm{J}_{1}=11.3 \mathrm{~Hz}$ e $\mathrm{J}_{2}=2.6 \mathrm{~Hz}, 1 \mathrm{H}$,
$\mathrm{CH}), 1.81-1.08(\mathrm{~m}, 10 \mathrm{H}), 1.37\left(\mathrm{~s}, 6 \mathrm{H},-\mathrm{CH}_{3}\right) ;{ }^{13} \mathrm{C}-\mathrm{NMR}$ $\left(\mathrm{CDCl}_{3}, 75 \mathrm{MHz}\right) \delta 200.99,168.97,78.67,74.72,58.27$, 49.82, 29.91, 26.96, 26.04, 26.01; MS (70 eV): m/z (\%) = $223\left(\mathrm{M}^{+}\right), 140$ (100), 113, 98, 72, 55; IR (KBr) 3261, 1637, $1545 \mathrm{~cm}^{-1}$; Anal. Calcd. for $\mathrm{C}_{13} \mathrm{H}_{21} \mathrm{NO}_{2}$ : C, 69.9; H, 9.5; N, 6.3. Found: C, 71.1; H, 9.6; N, 6.2.

Physical and spectroscopic data for $4 \mathbf{d}$ : $\mathrm{mp}$ 60-62 ${ }^{\circ} \mathrm{C}$. ${ }^{1} \mathrm{H}-\mathrm{NMR}\left(\mathrm{CDCl}_{3}, 400 \mathrm{MHz}\right) \delta 4.88(\mathrm{~s}, 1 \mathrm{H},-\mathrm{C}=\mathrm{CH}-), 4.07$ (s, 2H, $\left.-\mathrm{CH}_{2} \mathrm{O}-\right), 2.25$ (t, $\left.\mathrm{J}_{1}=8,0 \mathrm{~Hz}, 2 \mathrm{H},-\mathrm{CO}-\mathrm{CH}_{2}-\right), 1.59$ (quint., $\left.\mathrm{J}=7.6 \mathrm{~Hz}, 2 \mathrm{H},-\mathrm{CH}_{2}-\right), 1.39\left(\mathrm{~s}, 6 \mathrm{H},-\mathrm{CH}_{3}\right), 1.34-$ $1.25\left(\mathrm{~m}, 4 \mathrm{H},-\mathrm{CH}_{2}-\right), 0,88\left(\mathrm{t}, \mathrm{J}=6.8 \mathrm{~Hz}, 3 \mathrm{H},-\mathrm{CH}_{3}\right)$; ${ }^{13} \mathrm{C}-\mathrm{NMR}\left(\mathrm{CDCl}_{3}, 100 \mathrm{MHz}\right) \delta 197.62,168.39,78.66$, 76.21, 58.28, 41.94, 31.73, 27.03, 25.90, 22.56, 13.97; MS $(70 \mathrm{eV}): \mathrm{m} / \mathrm{z}(\%)=211\left(\mathrm{M}^{+}\right), 169,155,140(94), 113(100)$, 98, 72, 55; IR (KBr) 3251, 1630, $1541 \mathrm{~cm}^{-1}$; Anal. Calcd. for $\mathrm{C}_{12} \mathrm{H}_{21} \mathrm{NO}_{2}$ : C, 68.2; H, 10.0; N, 6.6. Found: C, 67.7; $\mathrm{H}, 10.2 ; \mathrm{N}, 6.8$.

Physical and spectroscopic data for 4e: $\mathrm{mp} 102-104{ }^{\circ} \mathrm{C}$. ${ }^{1} \mathrm{H}-\mathrm{NMR}\left(\mathrm{CDCl}_{3}, 300 \mathrm{MHz}\right) \delta 7.42-7.37$ (m, 1H, o-tolyl), 7.28-7.13 (m, 3H, tolyl), 5.17 (s, $1 \mathrm{H},-\mathrm{C}=\mathrm{CH}-), 4.15$ (s, 2H, - $\left.\mathrm{CH}_{2}-\mathrm{O}-\right), 2.46\left(\mathrm{~s}, 3 \mathrm{H},-\mathrm{CH}_{3}\right), 1.46\left(\mathrm{~s}, 6 \mathrm{H},-\mathrm{CH}_{3}\right) ;{ }^{13} \mathrm{C}-\mathrm{NMR}$ $\left(\mathrm{CDCl}_{3}, 75 \mathrm{MHz}\right) \delta 192.60,169.03,142.29,135.63$, 130.85, 128.83, 127.37, 125.41, 78.88, 77.85, 58.52, 27.04, 20.13; MS $(70 \mathrm{eV}): \mathrm{m} / \mathrm{z}(\%)=231\left(\mathrm{M}^{+}\right), 216(100), 203$, 188, 176, 159, 140 (12), 132, 119, 91, 65, 55; IR (KBr) 3220, 1623, $1532 \mathrm{~cm}^{-1}$; Anal. Calcd. for $\mathrm{C}_{14} \mathrm{H}_{17} \mathrm{NO}_{2}$ : C, 72.7; H, 7.4; N, 6.1. Found: C, 71.1; H, 7.5; N, 6.0.

\section{Theoretical Calculations}

\section{Atomic charges}

The cartesian coordinates of molecule $4 \mathbf{a}$ were obtained from X-ray data (present work) and converted to a format compatible with Hyperchem ${ }^{8}$. Mülliken charges ${ }^{9}$ were calculated using the semi-empirical INDO model ${ }^{10}$ built in the Hyperchem package ${ }^{8}$.

\section{Heats of formation}

The three isomeric molecules, $\beta$-keto-oxazoline 5a, enaminone $\mathbf{4 a}$ in configurations $Z$ and $E$ were built and geometry optimized with the AM1 model ${ }^{11}$ in the Hyperchem program ${ }^{8}$. The heats of formation of each optimized structures were calculated. The $Z$ configuration of $\mathbf{4 a}$ had to be constrained.

\section{Crystallographic studies}

Each crystal of enaminones $\mathbf{4 a}$ and $\mathbf{4 b}$ was mounted on the goniometer head of an Enraf-Nonius CAD4 diffractometer and the data were collected at 293(2) K using a highly oriented graphite monochromator and MoK $\alpha$ radiation $0.71073 \AA$. A summary of data collection and refinement ${ }^{12}$ can be seen in Table 1 . No absorption corrections were made because the absorption coefficients were low in 
both cases. The structures were solved by direct methods using the program SHELXS- $97^{13}$ which revealed the positions of most of the heavy atoms, the remaining heavy atoms were located in successive refinement cycles using the program SHELXL-97 ${ }^{13}$. Drawings were made with the program ZORTEP-II ${ }^{14}$. The asymmetric unit in the crystal of $4 \mathbf{a}$ corresponds to only one enaminone molecule whereas that of $\mathbf{4 b}$ is composed of four enaminone molecules (labeled A, B, C and D) and half water molecule of crystallization. The water molecule present in $\mathbf{4 b}$ was refined with $50 \%$ site occupancy. Hydrogen atoms were added in idealized positions and labeled according to the numbering of the heavy atoms attached to them (Fig. 2). No hydrogen atoms were added to the water oxygen atom. All heavy atoms were refined anisotropically in the last full matrix refinement, and no geometrical constraints were used. The hydrogen atoms were refined using a riding model.

\section{Results and Discussion}

\section{Synthesis and spectroscopy}

When anion $\mathbf{3}$ was allowed to reacted with an ester, a mixture of two compounds $\mathbf{4}$ and $\mathbf{5}$ was obtained, the major one being $4(>93 \%)$ showing the migration of the double bond as determined by ${ }^{1} \mathrm{H}-\mathrm{NMR}$ analysis (Scheme 1).
The intriguing presence of only one signal characteristic of vinylic hydrogen in the ${ }^{1} \mathrm{H}-\mathrm{NMR}$ spectrum of each of the five reaction mixtures indicates that the stereochemistry of the double bond of the enaminones was stabilized in one of the two possible configurations. Also intriguing were the chemical shifts of the two vinylic carbon atoms $\mathrm{C}(2)$ and $\mathrm{C}(8)$ at around 168 and $75 \mathrm{ppm}$ (Table 2) where the former is less shielded and the latter is more shielded than regular vinylic carbon atoms ${ }^{15}$. The calculated Mülliken charges (enaminone $4 \mathbf{a}$ ) of atom $\mathrm{C}(2)$ is much more positive than that of $\mathrm{C}(8)$ (Table 2) in accordance with the observed ${ }^{13} \mathrm{C}-\mathrm{NMR}$ shifts. This fact suggests that there exists a charge unbalance on these carbon atoms. The more shielded carbon atom must be acquiring an extra charge due to a $\pi$ conjugation whereas the less shielded one must be losing charge due to inductive effects of the bound nitrogen and oxygen atoms.

The $\mathrm{C}=\mathrm{O}$ stretching frequency of all five enaminones lies between 1614 and $1637 \mathrm{~cm}^{-1}$ and that of $\mathrm{C}=\mathrm{C}$ lies between 1532 and $1570 \mathrm{~cm}^{-1}$ and are characteristic of systems with extended $\pi$ conjugation ${ }^{16}$.

A peak at around $140 \mathrm{~m} / \mathrm{z}$ was located in the mass spectra of all five enaminones and was assigned to the their common segment left after the loss of the different $\mathrm{R}$

Table 1. Crystallographic data for enaminones $4 \mathbf{a}$ and $\mathbf{4 b}$.

\begin{tabular}{lcc}
\hline & 4a & 4b \\
\hline Formula of the asymmetric unit & $\mathrm{C}_{8} \mathrm{H}_{13} \mathrm{NO}_{2}$ & $\left(\mathrm{C}_{13} \mathrm{H}_{15} \mathrm{NO}_{2}\right)_{4} 0.5\left(\mathrm{H}_{2} \mathrm{O}\right)$ \\
Crystal system, space group & monoclinic, $\mathrm{P} 2(1) / \mathrm{n}$ & Monoclinic, $\mathrm{P} 2(1) / \mathrm{c}$ \\
$\mathrm{a}(\AA)$ & $9.145(2)$ & $16.052(3)$ \\
$\mathrm{b}(\AA)$ & $10.515(2)$ & $26.646(5)$ \\
$\mathrm{c}(\AA)$ & $9.567(2)$ & $12.352(2)$ \\
$\beta($ degree $)$ & $106.21(3)$ & $111.90(3)$ \\
Volume $\left(\AA^{3}\right)$ & $883.4(3)$ & $4902.0(15)$ \\
$Z$, calculated density & $4,1.167 \mathrm{~g} / \mathrm{cm}^{3}$ & $4,1.190 \mathrm{~g} / \mathrm{cm}^{3}$ \\
Reflections collected/unique & $1652 / 1548[\mathrm{R}(\mathrm{int})=0.0128]$ & $8737 / 8330[\mathrm{R}(\mathrm{int})=0.0221]$ \\
final $\mathrm{R}$ indices $[\mathrm{I}>2$ sigma(I)] & $\mathrm{R} 1=0.0495$ & $\mathrm{wR} 2=0.1385$ \\
$\mathrm{R}$ indices (all data) & $\mathrm{R} 1=0.0696$ & $\mathrm{wR} 2=0.1614$ \\
Absorption coefficient $\left(\mathrm{mm}^{-1}\right)$ & 0.084 & 0.081 \\
\hline
\end{tabular}<smiles>[R]C(=O)OCC</smiles><smiles>CC1=NC(C)(C)CO1</smiles>
$-10{ }^{\circ} \mathrm{C}, \mathrm{N}_{2}$ $65-75 \%$

2a-e

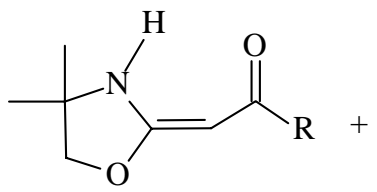

enaminone

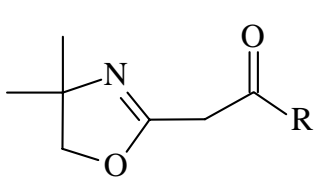

$\beta$-keto oxazoline

5a-e
$\mathrm{R}$

a: methyl

b: phenyl

c: cyclohexyl

d: n-pentyl

e: $p$-tolyl

Scheme 1.

4a-e 
Table 2. Selected ${ }^{13} \mathrm{C}-\mathrm{NMR}$ chemical shifts of five enaminones and the calculated Mülliken charges of enaminone 4a. See Fig. 2 for the atom numbering.

\begin{tabular}{lrrrrrc}
\hline & 4a & 4b & 4c & 4d & 4e & \multicolumn{1}{c}{$\begin{array}{c}\text { INDO/ } \\
\text { Mülliken } \\
\text { Charge 4a }\end{array}$} \\
\hline C (2) & 168.21 & 169.63 & 168.97 & 168.39 & 169.03 & 0.429 \\
C (4) & 58.23 & 58.58 & 58.27 & 58.28 & 58.52 & 0.134 \\
C (5) & 78.60 & 78.98 & 78.67 & 78.66 & 78.88 & 0.206 \\
C (8) & 76.76 & 74.07 & 74.72 & 76.21 & 77.85 & -0.296 \\
C (9) & 194.14 & 187.53 & 200.99 & 197.62 & 192.60 & 0.355 \\
\hline
\end{tabular}

substituents. It was observed that for nonaromatic R substituted molecules this peak was much more abundant than for the aromatic ones.

\section{Crystal structure}

In order to assign the stereochemistry of the double bond, it was decided to determine the crystal structures of enaminones $\mathbf{4 a}$ and $\mathbf{4 b}$ whose single crystals were obtained by dropwise addition of hexane to a warm solution of these compounds in ethyl acetate.

To follow the discussion below please refer to Tables 1 and 3 and to Fig. 2. The asymmetric unit of the single crystal of $\mathbf{4 b}$ has four enaminone molecules (labeled A, B, C and D) whereas that of $\mathbf{4 a}$ has only one. The intermolecular dihedral angle between the phenyl and the heterocyclic ring planes is 28.99(0.16), 20.15(0.12), 9.44(0.34) and 18.12(0.33) degrees for enaminone 4 b molecules A, B, C and $\mathrm{D}$, respectively. Despite this dihedral angle differences the other structural parameters are quite similar for all four molecules. These packing characteristics are responsible for the high cell volume exhibited by the crystal of $\mathbf{4 b}$ as compared to that of $\mathbf{4 a}$.

Enaminones $\mathbf{4 a}$ and $\mathbf{4 b}$ have configuration $E$ that is favored over the $Z$ due to the intermolecular hydrogen bonding N(3)-H(3)--- O(10). From the bond order assign-
Table 3. Selected bond lengths and assigned bond orders for enaminones 4a and $\mathbf{4 b}$. The bond order assignment is based on typical bond lengths for $\mathrm{C}-\mathrm{N}(1.47 \AA), \mathrm{C}=\mathrm{N}(1.37 \AA), \mathrm{CN}(1.16 \AA), \mathrm{C}-\mathrm{O}(1.43 \AA), \mathrm{C}=\mathrm{O}(1.23$ $\AA), \mathrm{C}-\mathrm{C}(1.54 \AA), \mathrm{C}=\mathrm{C}(1.37 \AA)$ and $\mathrm{CC}(1.20 \AA)$. Atom labels are shown in Fig. 2. The values given for enaminone $\mathbf{4 b}$ are average values for the four molecules A, B, C and D.

\begin{tabular}{|c|c|c|c|}
\hline $\begin{array}{l}\text { Bond length } \\
(\AA)\end{array}$ & $4 \mathbf{a}$ & $\begin{array}{c}\mathbf{4 b} \\
\text { (average) }\end{array}$ & bond order \\
\hline $\mathrm{N}(3)-\mathrm{H}(3)$ & $0.90(3)$ & $0.96(5)$ & - \\
\hline $\mathrm{O}(10)-\mathrm{H}(3)$ & $2.23(3)$ & $2.13(5)$ & - \\
\hline $\mathrm{C}(2)-\mathrm{N}(3)$ & $1.317(3)$ & $1.313(6)$ & slightly higher than 2 \\
\hline $\mathrm{C}(2)-\mathrm{O}(1)$ & $1.349(2)$ & $1.335(6)$ & $\begin{array}{l}\text { intermediate between } \\
1 \text { and } 2\end{array}$ \\
\hline$C(2)-C(8)$ & $1.369(3)$ & $1.366(7)$ & 2 \\
\hline $\mathrm{C}(8)-\mathrm{C}(9)$ & $1.403(3)$ & $1.410(7)$ & slightly less than 2 \\
\hline $\mathrm{C}(9)-\mathrm{O}(10)$ & $1.244(3)$ & $1.255(5)$ & 2 \\
\hline $\mathrm{C}(4)-\mathrm{N}(3)$ & $1.472(3)$ & $1.459(6)$ & 1 \\
\hline$C(4)-C(5)$ & $1.524(3)$ & $1.523(8)$ & 1 \\
\hline $\mathrm{C}(5)-\mathrm{O}(1)$ & $1.436(3)$ & $1.429(7)$ & 1 \\
\hline
\end{tabular}

ments ${ }^{17,18}$ given in Table 3 one can infer that the lone electron pairs of the nitrogen and oxygen atoms are conjugated with the adjacent $\pi$ system that extends over atoms $\mathrm{N}(3), \mathrm{C}(2), \mathrm{O}(1), \mathrm{C}(8), \mathrm{C}(9)$ and $\mathrm{O}(10)$.

The torsion angle formed by $\mathrm{N}(3)-\mathrm{C}(2)-\mathrm{C}(8)-\mathrm{C}(9)$ is less than $6^{\circ}$, in both structures, revealing that this part of the molecule is almost flat in accordance with the proposed extended $\pi$ delocalization.

In crystals $\mathbf{4 a}$ and $\mathbf{4 b}$ there are also intermolecular hydrogen bondings between the $\mathrm{H}(3)$ and $\mathrm{O}(10)$. In 4a this intermolecular contact is $2.13 \AA$ whereas in $\mathbf{4 b}$ it ranges from 2.17 to $2.28 \AA$. In $\mathbf{4 a}$ the intermolecular hydrogen bonding distance is shorter than the intramolecular one indicating that this kind of interaction plays an important role in the crystal packing.

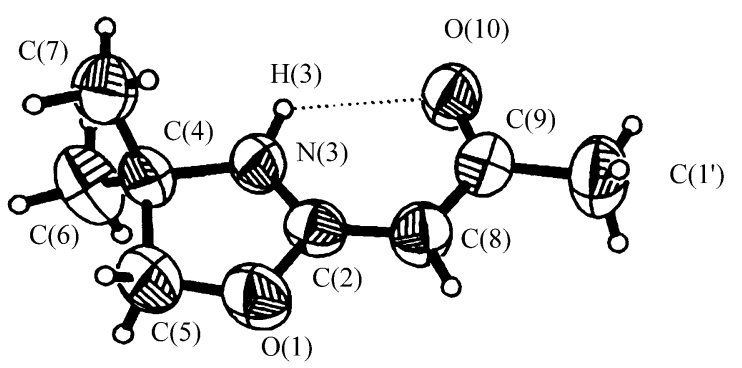

(4a)

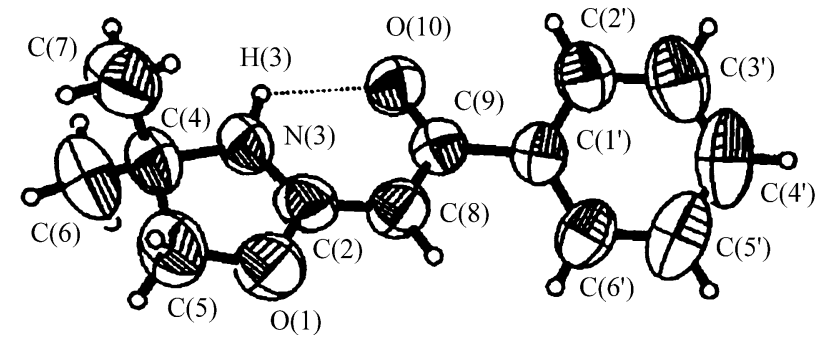

(4b)

Figure 2. Ortep drawing of enaminones $4 \mathrm{a}$ and $4 \mathrm{~b}$-(molecule A). Thermal ellipsoids are drawn to the $50 \%$ level. Hydrogen labels are not shown, except $\mathrm{H}(3)$. The dashed lines indicate the intramolecular hydrogen bonding. 


\section{Relative thermodynamic stability}

The methyl substituted system 4a was selected as a representative of the series for the estimation of the relative stability of isomers $\beta$-keto-2-oxazoline and enaminone in configurations $E$ and $Z$.

The calculated heat of formation of enaminone $4 \mathbf{a}$ in the $E$ configuration is $23.3 \mathrm{~kJ} /$ mole lower than that for the $\beta$-keto-2-oxazoline 5a in accordance with their relative abundance in solution as observed in the ${ }^{1} \mathrm{H}-\mathrm{NMR}$ spectrum. The calculated heat of formation of the $E$ isomer of $\mathbf{4 a}$ is $26.4 \mathrm{~kJ} / \mathrm{mole}$ lower than that for the $Z$ isomer suggesting that the former is thermodynamically favored, as observed in the crystal structure of enaminone $\mathbf{4 a}$.

\section{Conclusion}

In an attempt to prepare five $\beta$-keto-2-oxazolines by the reaction of 2,4,4-trimethyl-2-oxazoline anion with five esters we have obtained the isomeric enaminones instead. The five enaminones were characterized by ${ }^{1} \mathrm{H}-\mathrm{NMR},{ }^{13} \mathrm{C}$ NMR, FTIR and GC-MS techniques. Two enaminones were analysed by single crystal X-ray diffraction and one of them was subjected to theoretical calculations.

The common segment of two enaminone molecules have quite similar crystal structural parameters and correspond to the $E$ configuration of the double bond. The NMR shifts of the carbon and hydrogen atoms of the common segment of the five enaminones are also alike. These two analyses allowed us to conclude that the common segment has similar electronic structure and that the double bond is in the $E$ configuration in all five enaminones.

The double bond is stabilized in the configuration $E$ due to the internal hydrogen bond, $\mathrm{N}-\mathrm{H}---\mathrm{O}=\mathrm{C}$, either in the solid state or in a non polar solvent such as chloroform. Analogous compounds were reported to show this behavior $^{19}$. The calculated heat of formation of the enaminone $E$ is lower than those of enaminone $Z$ and $\beta$-keto-2-oxazoline molecules, in agreement with the experimental evidence.

From the analysis of bond orders (based on bond lengths), ${ }^{13} \mathrm{C}$ chemical shifts, and $\mathrm{C}=\mathrm{O}, \mathrm{C}=\mathrm{C}$ stretching frequencies, it was possible to detect an extensive delocalization of the lone electron pairs of the enaminone nitrogen and oxygen atoms over the adjacent vinyl and carbonyl $\pi$ system.

Considering that the enaminone and the $\beta$-keto-2-oxazoline forms could be in equilibrium in solution it might be possible to reduce them with baker's yeast to the $\beta$-hydroxy-2-oxazoline form. This possibility is currently being tested.

\section{Supplementary Material}

Crystallographic data (excluding structure factors) for the structures in this paper have been deposited with the
Cambridge Crystallographic data Center as supplementary publication CCDC, 116080 (enaminone 4a), 116081 (enaminone 4b).

Copies of the data can be obtained free of charge, on application to CCDC, 12 Union Road, Cambridge CB21EZ, UK (fax + 441223 336033) or e-mail deposit@ccdc.camac.uk

\section{Acknowledgments}

We thank FUNPAR, CNPq/PADCT for financial support, to Prof. Ivo Vencato, Analytical Center of UFSC for the collection and interpretation of crystal data. We also thank Prof. J.D. da Motta from DQUI-UFPR for his support in theoretical calculations.

\section{References}

1.a) Simonelli, F.; Oliveira, A.R.M.; Marques, F.A.; Gomes, A.L.; Echterhoff, M.R.F.; Santos, A.A. Abstracts of the $18^{\text {th }}$ Annual Meeting of the Brazilian Society of Chemistry 1995, QO 086; b) Oliveira, A.R. M.; Marques, F.A.; Simonelli, F.; Santos, A.A.; Abstracts of $8^{\text {th }}$ Brazilian Meeting on Organic Synthesis 1998, PS-031, p 78.

2. Morrison, J.D. Asymmetric Synthesis; Academic Press: 1984.

3. Frump, J.A. Chem. Rev. 1971, 71, 483.

4. Nogradi, M. Stereoselective Synthesis; VCH: 1986. Chapt. 2 and 3.

5. a) Servi, S. Synthesis 1990, 1; b) Csuk, R.; Glanzer, B.I. Chem. Rev. 1991, 91, 49.

6. a) Akita, H.; Furuichi, A.; Koshiji, K.; Oishi, T. Tetrahedron Lett. 1982, 23, 4051; b) Horikoshi, K.; Furuichi, A.; Koshiji, K., Akita, H.; Oishi, T. Agric. Biol. Chem. 1983, 47, 435.

7. Fantin, G.; Fogagnolo, M.; Medici, A.; Pedrini, P.; Poli, S.; Gardini, F.; Guerzoni, M.E. Tetrahedron: Asymmetry 1991, 2, 243.

8. Hyperchem Program Version 4.5, Hypercube Inc., Gainesville, Florida, USA.

9. Szabo, A.; Ostlund, N.S. In Modern Quantum Chemistry Mc Graw Hill, ${ }^{\text {st }}$ Edition, 1989.

10. Pople, J.A.; Beveridge, D.; Dobosh, P. J. Chem. Phys. 1967, 47, 2026.

11. Dewar, M.J.S.; Zoebish, E.G.; Healy, E.F. J. Am. Chem. Soc. 1985, 107, 3902.

12. Enraf-Nonius. CAD-4 Express Software. Version1.1. Enraf-Nonius, Delft, The Netherlands, 1993.

13. Sheldrick, G.M. SHELX-97. Program for the Refinement and Solution of Crystal Structures. Univ. of Göttingen.

14. Zsolnai, L. ZORTEP. An Interative ORTEP Program; University of Heidelberg, Germany. 
15. Breitmaier, E.; Voelter, W. In Carbon-13 NMR Spectroscopy: High Resolution Methods and Applications in Organic Chemistry and Biochemistry; VCH: Weinheim, $3^{\text {rd }}$ Edition, 1987.

16. Silverstein, R.M.; Bassler, G.C.; Morrill, T.C. In Spectrometric Identification of Organic Compounds, John Wiley \& Sons, $5^{\text {th }}$ Edition, 1991.
17. Cunha, C.J. da; Fielder, S.S.; Stynes, D.V.; Masui, H.; Auburn, P.R.; Lever, A.B.P. Inorg. Chim. Acta 1996 242, 293.

18. Wycoff, R.W.G. In Crystal Structures; John Wiley \& Sons; 2nd Edition, 1969.

19. Dixit, A.N.; Reddy, K.V.; Deshmukh, A.R.A.S.; Rajappa, S.; Ganguly, B.; Chandrasekhar, J. Tetrahedron 1995, 51, 1437 and references cited therein.

Received: March 26, 1999 